\title{
Friend retrovirus drives cytotoxic effectors through Toll-like receptor 3
}

\author{
Kathrin Gibbert ${ }^{*}$, Sandra Francois ${ }^{1}$, Anna M Sigmund ${ }^{2}$, Michael S Harper ${ }^{3}$, Bradley S Barrett ${ }^{3}$, Carsten J Kirchning ${ }^{2}$, \\ Mengji Lu', Mario L Santiago ${ }^{3}$ and Ulf Dittmer ${ }^{1}$
}

\begin{abstract}
Background: Pathogen recognition drives host defense towards viral infections. Specific groups rather than single members of the protein family of pattern recognition receptors (PRRs) such as membrane spanning Toll-like receptors (TLRs) and cytosolic helicases might mediate sensing of replication intermediates of a specific virus species. TLR7 mediates host sensing of retroviruses and could significantly influence retrovirus-specific antibody responses. However, the origin of efficient cell-mediated immunity towards retroviruses is unknown. Double-stranded RNA intermediates produced during retroviral replication are good candidates for immune stimulatory viral products. Thus, we considered TLR3 as primer of cell-mediated immunity against retroviruses in vivo.

Results: Infection of mice deficient in TLR3 (TLR3 ${ }^{-/}$) with Friend retrovirus (FV) complex revealed higher viral loads during acute retroviral infection compared to wild type mice. TLR3 ${ }^{-1-}$ mice exhibited significantly lower expression levels of type I interferons (IFNs) and IFN-stimulated genes like Pkr or Ifi44, as well as reduced numbers of activated myeloid dendritic cells (DCs) $\left(C D 86^{+}\right.$and $\left.M H C-I^{+}\right)$. DCs generated from $\mathrm{FV}_{\text {-infected TLR3 }}{ }^{-/-}$mice were less capable of priming virus-specific $C D 8^{+} T$ cell proliferation. Moreover, cytotoxicity of natural killer (NK) cells as well as $C D 8^{+} T$ cells were reduced in vitro and in vivo, respectively, in $\mathrm{FV}$-infected $\mathrm{TLR3}^{-1-}$ mice.
\end{abstract}

Conclusions: TLR3 mediates antiretroviral cytotoxic NK cell and CD8 ${ }^{+} \mathrm{T}$ cell activity in vivo. Our findings qualify TLR3 as target of immune therapy against retroviral infections.

Keywords: Toll-like receptor 3, Friend Retrovirus, Dendritic cells, NK cells, Cytotoxic T cells, Pathogen recognition

\section{Background}

The host immune system offers a variety of different innate receptors to sense invading viruses. These pattern recognition receptors (PRR) recognize pathogen-associated molecular pattern (PAMPs), which are highly conserved molecular structures produced by pathogens but not by the host cells. One important family of PRRs includes the Toll-like receptors (TLRs) that span cell or endosomal membranes. The latter include TLR3, TLR7/8 and TLR9 which recognize double-stranded RNA (dsRNA), singlestranded RNA or CpG-containing DNA, respectively (reviewed in [1]). Cytosolic PRRs such as cyclic GMPAMP synthase (cGAS), retinoic acid inducible gene I (RIG-I) and Melanoma Differentiation-Associated protein 5 (MDA5) also sense replication intermediates of

\footnotetext{
* Correspondence: Kathrin.Gibbert@uni-due.de

${ }^{1}$ Institute for Virology of the University Hospital in Essen, University of

Duisburg-Essen, Essen, Germany

Full list of author information is available at the end of the article
}

numerous viruses [2-4]. Virus sensing PRRs principally mediate induction of type I interferon (IFN) production and thus expression of interferon-stimulated genes to elicit an antiviral state in the cell. Many viruses have developed mechanisms to evade their host sensors resulting in impaired host immunity (reviewed in [5]). Redundancy in virus recognition, namely employment of a specific set of multiple PRRs, prevents viral escape from host surveillance.

Studies in vitro revealed that multiple PRRs such as DC-SIGN, TLR7/8, TLR9, cGAS and TRIM5 $\alpha$ sense retroviruses including HIV and SIV (reviewed in [2,6-10]). However, in vivo studies determining their impact in directing antiretroviral innate and adaptive immune responses remains limited. Using knockout mice, myeloid differentiation primary response 88 (MyD88) and TLR7dependent viral sensing were previously shown as critical for the development of neutralizing antibody responses against murine leukemia virus (MuLV) infections $[11,12]$. 
However, the induction of $\mathrm{T}$ cell responses only partially depended on the MyD88-TLR7 pathway [11,12]. The impact of innate sensing mechanisms on Natural Killer (NK) cell responses, which are also critical for antiretroviral immunity $[13,14]$, remains unknown.

In this report, we investigated whether the dsRNA sensor TLR3 [15] is involved in retrovirus sensing. Duplex formation of retroviral RNA prior to reverse transcription may occur during retroviral life cycle [16] and higher order dsRNA structures like stem loops located in retroviral long-terminal repeats were described $[17,18]$. To investigate the impact of TLR3 during retroviral infections in vivo, we used the Friend Retrovirus (FV) mouse model. The FV complex is comprised of two retroviruses: the replication-competent helper virus called Friend murine leukemia virus (F-MuLV), which is nonpathogenic in adult mice, and the replication-defective, pathogenic spleen focus-forming virus (SFFV) [19]. FV induces erythroleukemia in susceptible mice. In contrast, resistant strains, such as the C57BL/6 mice that were used in the current study, mount potent immune responses during acute infection to recover from disease [20]. Our findings provide evidence that TLR3 mediates retroviruses sensing which impacts early cellular antiretroviral immune response in vivo.

\section{Results}

\section{Increased viremia in $\mathrm{TLR}^{-/-}$mice}

Deletion of MyD88 in mice did not result in a significant increase in acute FV viremia [11,12], suggesting the existence of alternative sensing pathways. Since TLR3 is activated through TIR-domain-containing adapter-inducing interferon- $\beta$ (TRIF) [21-23], we tested if TLR3 is involved in immune recognition of retroviruses. Thus, we infected wild type mice $\left(\mathrm{TLR}^{+/+}\right.$) and mice deficient in TLR3 $\left(\mathrm{TLR}^{-/-}{ }^{-}\right.$) with FV and analyzed the viral loads at days 4 and 10 post infection. At both time points, a significant increase in viral loads was detected in $\mathrm{TLR}^{-1-}$ mice
(Figure 1). At the earlier time point the mean viral burden was up to 4 times higher in TLR3 ${ }^{-/}$compared to wild type mice (Figure 1A) and the effect was even stronger at 10 dpi ( $>18$-fold; Figure 1B). In contrast, TLR7 deficiency in mice did not impact acute FV infection (Figure 1C; 7 dpi). These data indicate that TLR3 sensing contributes to immune control of FV during the acute phase of infection.

\section{Impaired DC activation in FV-infected TLR3 ${ }^{-/-}$mice}

As TLR3 is mainly expressed by myeloid DCs (mDCs) and macrophages (reviewed in [24,25]), but not plasmacytoid DCs or T cells, we analyzed the impact of TLR3 sensing on the activation and maturation of $\mathrm{mDCs}$ and macrophages during acute FV infection (4 dpi). Firstly, we measured if the expression level of this receptor is up-regulated in $\mathrm{mDCs}$ during $\mathrm{FV}$ infection. As depicted in Figure 2A, Tlr3 mRNA was detectable in mDCs of both uninfected, as well as FV-infected mice, whereas the relative expression levels did not differ significantly. As downstream signaling of TLR3 leads to the induction of type I IFN and subsequent expression of interferonstimulated genes (ISG), we analyzed antiviral gene expression during acute $\mathrm{FV}$ infection in $\mathrm{TLR}^{-/-}$and $\mathrm{TLR}^{+/+}$mice. Therefore, we isolated total mRNA from mDCs of $\mathrm{FV}$-infected $\mathrm{TLR}^{-/-}$and $\mathrm{TLR}^{+/+}$mice and analyzed the expression of specific ISGs ( $P k r$, Ifi44) as well as the early type I IFNs (Ifn-a4, Ifn-b). Expression levels of all of the 4 mRNAs analyzed were increased during FV-infection compared to uninfected controls (data not shown), however mDCs of FV-infected TLR3 ${ }^{-/-}$ mice had reduced expression levels in comparison to those of infected $\mathrm{TLR}^{+/+}$mice (Figure $2 \mathrm{~B}$ ). The overall expression level of type I IFNs during FV infection in wild type mice was quite low which is in line with previous data from our group [26,27]. As the total numbers of $\mathrm{mDCs}$ in the spleen did not vary significantly in $\mathrm{FV}_{\text {-infected } \mathrm{TLR}^{+/+}}$and TLR3 ${ }^{-/}$mice (data not shown), we next analyzed the activation of $\mathrm{mDCs}$ which was
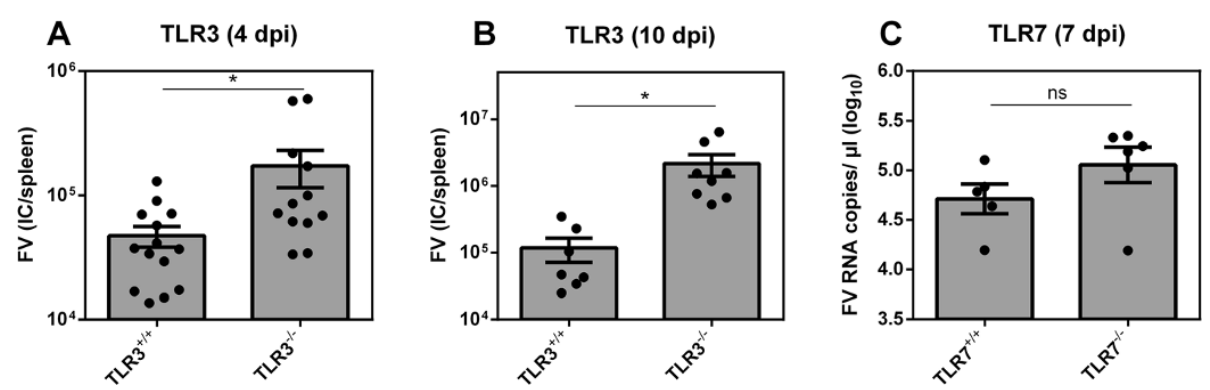

Figure 1 Viral loads in FV-infected TLR3 ${ }^{-/-}$and $\mathrm{TLR7}^{-/-}$mice. $\mathrm{TLR}^{+/+}$and $\mathrm{TLR}^{-/-}$mice were infected with $20,000 \mathrm{SFFU}$ of FV and viral loads in the spleen were determined by infectious center assay at days 4 (A) and 10 (B) post infection. In addition, plasma viral loads from FV-infected $\mathrm{TLR}^{-/-}$and TLR7 ${ }^{+/+}$mice at $7 \mathrm{dpi}$ were measured by $\mathrm{gPCR}$ (C). At least five mice per group were analyzed. Individual percentages and mean values are indicated by bars and dots + SEM. Statistically significant differences between FV-infected $\mathrm{TLR}^{+/+}$and $\mathrm{TLR}^{-/-}$mice are indicated by * for $p<0.05$ 

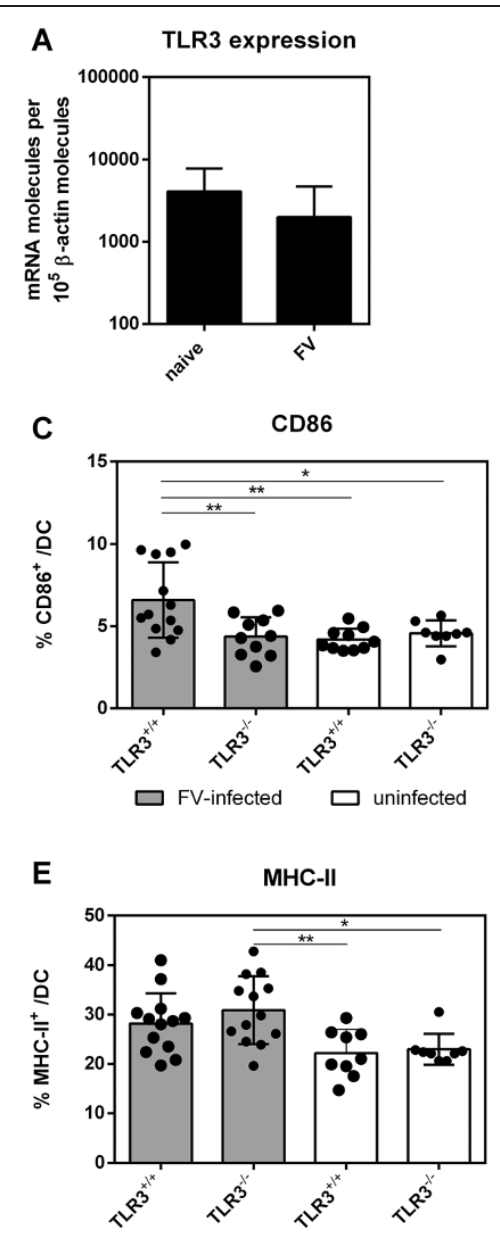

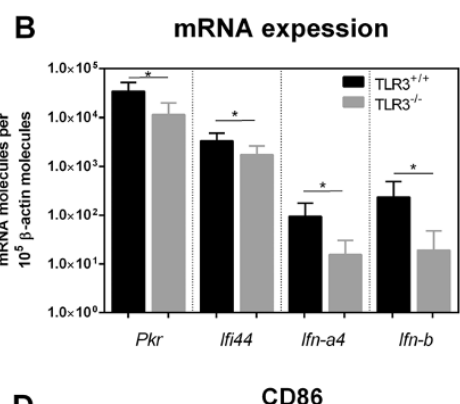

D
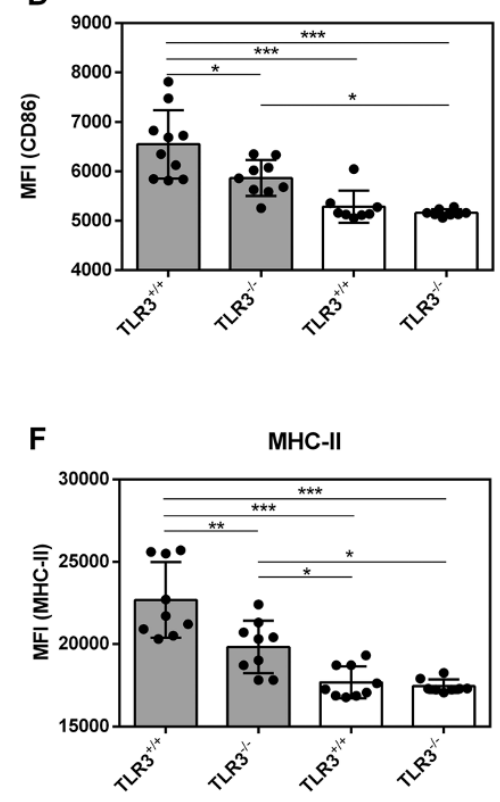

Figure 2 Phenotypic analysis of splenic DCs in FV-infected mice. TLR3 ${ }^{+/+}$and TLR3 ${ }^{-/-}$mice were infected with 20,000 SFFU of FV. At 4 dpi splenic DCs were isolated and analyzed for T/r3 mRNA expression (A) and mRNA expression of Pkr, Ifi44, Ifn-a4 and Ifn-b (B). Splenic DCs (CD11 $c^{+}$ $\mathrm{CD}_{1} \mathrm{~b}^{+}$) were also analyzed by flow cytometry. Surface expression of the costimulatory molecule CD86 (C, D) and MHC-II $(\mathbf{E}, \mathbf{F})$ were determined. Uninfected TLR3 ${ }^{+/+}$and TLR3 ${ }^{-/-}$mice were used as controls (white bars). A minimum of nine mice per FV-infected group were analyzed and the individual values are indicated by bars and dots + SEM. Experiments were repeated at least twice. Statistically significant differences between the groups are indicated by * for $p<0.05$, ** for $p<0.01$ and ${ }^{* * *}$ for $p<0.001$.

measured by the surface expression of the costimulatory molecule CD86 and major histocompatibility complex class II (MHC-II). Although the overall activation of mDCs during FV infection was low, $\mathrm{mDCs}$ were significantly higher activated during FV infection than in uninfected control mice (TLR3 ${ }^{-/-}$or $\mathrm{TLR}^{+/+}$mice). In FV-infected mice a significantly reduced percentage of $\mathrm{CD} 6^{+}$mDCs was detected in $\mathrm{TLR}^{-/-}$mice in comparison to $\mathrm{TLR}^{+/+}$mice (Figure $2 \mathrm{C}$ ) and a reduced mean fluorescence intensity of CD86 on mDCs of FV-infected $\mathrm{TLR}^{-1-}$ mice was found (Figure 2D). While infected $\mathrm{TLR}^{-/-}$mice did not have lower percentages of MHC- $\mathrm{II}^{+}$ $\mathrm{mDCs}$ compared to wild type mice (Figure $2 \mathrm{E}$ ), the surface expression levels of MHC-II on these cells were significantly decreased in FV-infected TLR3 ${ }^{-/-}$mice (Figure 2F). In contrast, the absolute numbers of macrophages in the spleen of FV-infected wild type and $\mathrm{TLR}^{-/-}$mice, as well as their activation status, did not differ (data not shown). Thus, TLR3 enhanced expression of type I IFNs and antiviral ISGs as well as activation of mDCs upon FV infection.

\section{NK cell cytotoxicity depends on TLR3}

Since mDCs bridge pathogen recognition and immune responses, we investigated effector functions of specific immune cell populations. As TLR3 already had an impact on viral loads at 4 dpi (Figure 1A), we analyzed the numbers and effector functions of NK cells at this early time point [14]. We did not find an increase in total numbers of NK cells $\left(\mathrm{NK} 1.1^{+} \mathrm{CD}_{49 \mathrm{~b}^{+}} \mathrm{CD}^{-}{ }^{-}\right)$or percentages of activated (CD69) NK cells in the spleen of FV-infected mice compared to uninfected control mice (Figure 3A, and data not shown). Moreover, no significant difference in NK cell activation was observed between FV-infected 

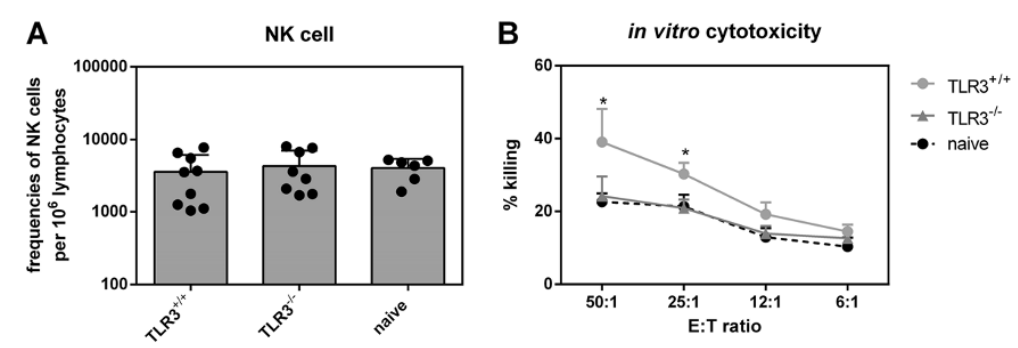

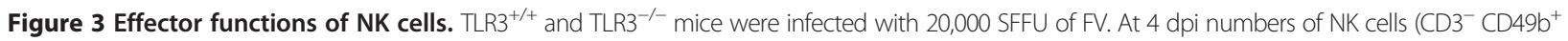
$\left.\mathrm{NK} 1.1^{+}\right)$in the spleen of FV-infected or naive mice were analyzed by flow cytometry (A). At least six mice of minimum two independent experiments were used and the mean values are shown by bars and dots + SEM. The cytotoxic potential of splenic NK cells was analyzed in an in vitro NK cell cytotoxicity assay. NK cells were isolated from spleens of FV-infected $\mathrm{TLR}^{+/+}$and $\mathrm{TLR}^{-/-}$mice (B). FV-derived tumor cells (FBL-3) were stained with CFSE and co-cultured with isolated NK cells at different effector-target ratio of 50:1 to 6:1 for $24 \mathrm{~h}$. At least four mice were used for the analysis. Statistically significant differences between the groups of infected TLR3 ${ }^{+/+}$and TLR3 ${ }^{-/-}$mice are indicated by * for $p<0.05$.

$\mathrm{TLR}^{-/-}$and wild type mice (Figure 3A). However, using an in vitro cytotoxicity assay, we observed a significant decrease in killing of FV-derived tumor cells (FBL-3) by NK cells isolated from $\mathrm{FV}$-infected TLR3 ${ }^{-/-}$mice in contrast to NK cells from wild type mice (Figure 3B). NK cells from FV-infected wild type mice were twice as effective in killing target cells as those from $\mathrm{TLR}^{-/-}$mice. Their killing capacity was very low, at comparable levels of NK cells from naive control mice. Thus, TLR3 is required for cytotoxic NK cell responses during acute FV infection.

\section{Impaired T cell responses in TLR3-deficient FV-infected mice}

We next investigated $\mathrm{T}$ cell responses at 10 days post infection, when viral loads in TLR $3^{-/-}$mice were prominently higher than in wild type mice (Figure 1B). Firstly, we analyzed if DCs from FV-infected TLR3 ${ }^{-1-}$ mice had an altered capacity to stimulate $\mathrm{CD}^{+} \mathrm{T}$ cell proliferation in vitro. We generated bone marrow (BM) derived DCs isolated from $\mathrm{FV}$-infected $\mathrm{TLR}^{-/-}$and $\mathrm{TLR}^{+/+}$mice and loaded these with a FV-specific $\mathrm{CD}^{+} \mathrm{T}$ cell epitope peptide. Afterwards, peptide-loaded BM-DCs were cocultured with CFSE-labeled FV-specific TCR transgenic $\mathrm{CD}^{+} \mathrm{T}$ cells and $\mathrm{T}$ cell proliferation was measured. As shown in Figure 4A, T cell stimulation with BM-DCs generated from $\mathrm{TLR}^{-/-}$mice resulted in lower numbers of proliferating $\mathrm{CD}^{+} \mathrm{T}$ cells (fewer $\mathrm{CD}^{+} \mathrm{T}$ cell proliferation cycles) than those of wild type mice. This decrease was also seen in a representative histogram in Figure $4 \mathrm{~B}$ showing that the proportion of cells particularly in the fourth daughter population (left peak; generation 4) was strongly reduced in cultures with BM-DCs generated from $\mathrm{TLR}^{-/-}$mice. The data implicate TLR3 in priming of FV-specific $\mathrm{CD}^{+} \mathrm{T}$ cells.

To monitor effector $\mathrm{T}$ cell responses during acute FV infection in TLR3-deficient and wild type mice, we infected these mice with 20,000 SFFU of FV. At $10 \mathrm{dpi}$, splenocytes were analyzed for $\mathrm{CD}^{+}$and $\mathrm{CD} 8^{+} \mathrm{T}$ cell responses. We did not detect a difference in the overall percentage of activated $\left(\mathrm{CD}_{4} 3^{+} \mathrm{CD} 2 \mathrm{~L}^{-}\right) \mathrm{CD}^{+} \mathrm{T}$ cells (Figure 5A). However, significantly lower numbers of virus-specific $\mathrm{CD}^{+}{ }^{+} \mathrm{T}$ cells were detected in $\mathrm{FV}$-infected $\mathrm{TLR}^{-1-}$ mice (Figure 5B). We observed no difference in the expression of IFN- $\gamma$ (Figure 5C), IL-2 (Figure 5D) or TNF- $\alpha$ (Figure $5 \mathrm{E}$ ) indicating that $\mathrm{CD}^{+}{ }^{+} \mathrm{T}$ cell functions did not depend on TLR3 during acute FV infection. Next, we analyzed $\mathrm{CD}^{+} \mathrm{T}$ cells, which are key players in anti-FV immunity [28,29]. In comparison to TLR3deficient mice, wild type mice had significantly higher percentages of activated $\left(\mathrm{CD}_{4} 3^{+}\right.$, Figure $\left.5 \mathrm{~F}\right)$ as well as virus-specific $\mathrm{CD}^{+} \mathrm{T}$ cells measured by tetramer staining (Figure 5G). To address if the impaired activation of the $\mathrm{CD}^{+} \mathrm{T}$ cells correlated with reduced cytotoxic effector functions and consequently higher viral loads (Figure 1), we performed an in vivo CTL assay. We observed a significantly higher killing of FV peptidelabeled target cells in wild type mice (mean: 85\%) in contrast to $\mathrm{TLR}^{-/-}$mice (mean: 62.5\%; Figure $5 \mathrm{H}$ ). These results demonstrate that TLR3 is essential for the induction of potent cytotoxic $\mathrm{CD}^{+} \mathrm{T}$ cell effector functions during acute FV infection.

\section{Discussion}

Efficient sensing by the innate immune system is the first step towards an effective antiviral immune response. In an effort to determine which innate sensing pathways are critical for retrovirus infections in vivo, mice deficient in various innate sensors were infected with murine retroviruses such as MuLV. Previously, it was shown that TLR7 and MyD88 were required for a potent antiretroviral humoral immune response $[11,12]$. However, $\mathrm{T}$ cell responses were only partially affected by MyD88 signaling, and no data exists on sensors required for NK cell activity. Here, we demonstrate for the first time that TLR3 sensing is involved in cytotoxic T cell and NK cell responses during acute $\mathrm{FV}$ infection.

Interestingly, no differences in viral loads were observed between wild type and MyD88-deficient mice 

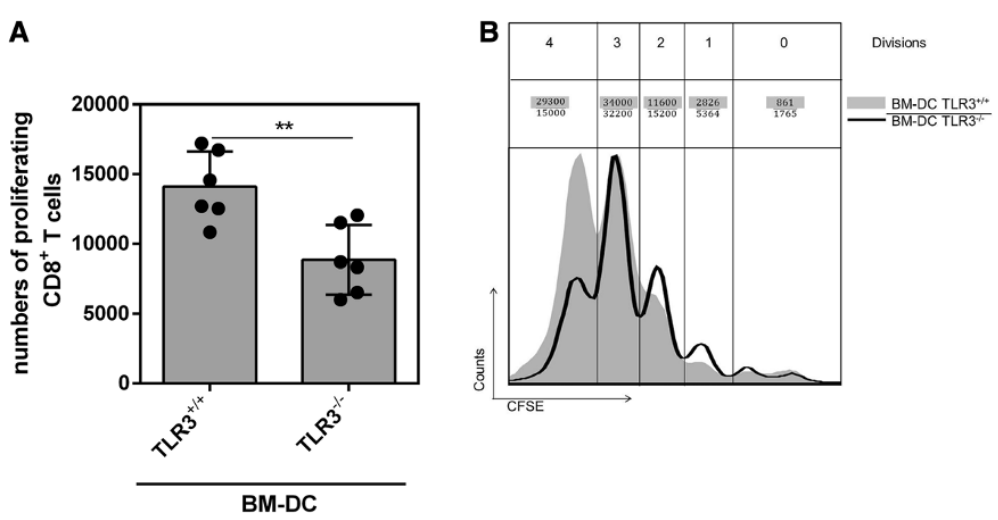

Figure 4 Proliferation of FV-specific $\mathrm{CD}^{+} \mathbf{T}$ cells in vitro. $\mathrm{TLR}^{+/+}$and $\mathrm{TLR} 3^{-/-}$mice were infected with 20,000 SFFU of FV. At 4 dpi bone marrow cells were isolated and cultured for 7 days to obtain BM-DCs. BM-DCs were loaded with FV GagL peptide and co-cultured with CFSE-labeled FV-specific CD8 $8^{+} T$ cells for 3 days. Proliferation of transgenic $C D 8^{+} T$ cells was determined by flow cytometry by loss of CFSE dye as calculated numbers of proliferating cells (A) or a representative histogram showing the amount of cells in each generation (B). A minimum of six mice were used for analysis. At least two independent experiments were performed. Significant differences between the groups are indicated by * for $p<0.05$.

during acute infection (up to 1 week post infection) [11]. Our data showing that TLR7 does not impact acute FV infection (see Figure 1C) is consistent with this finding, but contrasts recent data from the same group [30]. We hypothesize that the lack or inconsistent impact of TLR7/MyD88 on acute FV infection may reflect the fact that the neutralizing antibody responses do not play a significant role in inhibiting FV at the earliest infection time points [31]. Notably, at later time points (starting 2 weeks post infection) viral loads were increased in

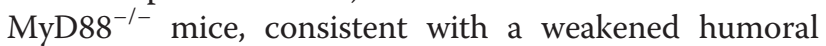
immune response. We recently provided evidence that NK cell responses could significantly inhibit acute FV replication in vivo [14]. Thus, our findings showing enhanced acute FV replication in $\mathrm{TLR}^{-/-}$mice are consistent with a strong impact of TLR3 on cytotoxic NK cell responses. TLR3 is strongly expressed by mDCs, whereas its expression is weak in murine B cell subsets [32]. In contrast, TLR7 is highly expressed by follicular B, marginal zone B, Peyer's patch B and B-1B cells and the expression level in mDCs is rather low [32]. This may explain that TLR7 is required for efficient antibody responses $[11,12]$ as it might directly influence B cell responses and not NK or T cell responses.

Other known innate sensors for retroviral infections are cGAS [2], DC-Sign [6], TLR9 [33] and zinc-finger antiviral protein [34]. They were all observed to be important for induction of type I IFN by retroviruses, but their influence on cellular or humoral immune responses has not been investigated so far. Antiviral immune responses can be affected by many sensors, which were described for other virus infections. This depends on the host cell type and on the time point of the infection. Especially TLRs are not ubiquitously expressed, but rather by specific immune cells like mDCs, pDCs, macrophages, B cells and others [35-37]. Other PRRs like MDA5 or Rig-I are found in the cytosol of almost every cell type making them efficient general sensors for viral infections. For influenza virus infection various PRRs were shown to be required for efficient induction of anti-viral immune responses. Influenza virus infection is sensed by many different PRRs (TLR3, TLR7 and Rig-I) (reviewed in [38]), and they all have distinct influences on the cellular and humoral immune responses against the virus. It was shown that TLR3, TLR7 and MyD88 signaling is not required for efficient $\mathrm{T}$ responses during influenza infection $[39,40]$, but both TLR7 and MyD88 are critical for B cell responses during influenza infection [40]. Koyama and colleagues investigated that Rig-I is also not needed for a potent $\mathrm{CD} 8^{+} \mathrm{T}$ cell response, whereas $\mathrm{B}$ cells and $\mathrm{CD} 4^{+} \mathrm{T}$ cells require MyD88 and Rig-I [39]. West Nile virus (WNV) vaccination studies revealed that MyD88 and TLR3 are both required for efficient humoral immune responses [41], and during a WNV infection Rig-I and MDA5 [42-44], as well as TLR3 and TLR7 $[45,46]$ are involved in immune recognition. Infection with Theiler`s murine encephalomyelitis virus requires sensing of both TLR3 and MDA5 $[47,48]$. Tabeta and colleagues reported that during mouse cytomegalovirus infection deficiency of TLR3 and TLR9 increases the infection due to reduced type I IFN secretion and NK cell activation [49]. This demonstrates that in many viral infections immune responses are initiated by various sensors and distinct PRRs have unique roles during viral defense.

Toll-like receptor 3 recognizes double-stranded RNA during viral infections [15]. Retroviruses consist of two single-stranded RNA strands which are entwined within the core. Together with the viral proteins they build a dimeric RNA complex [50]. These RNA strands form 


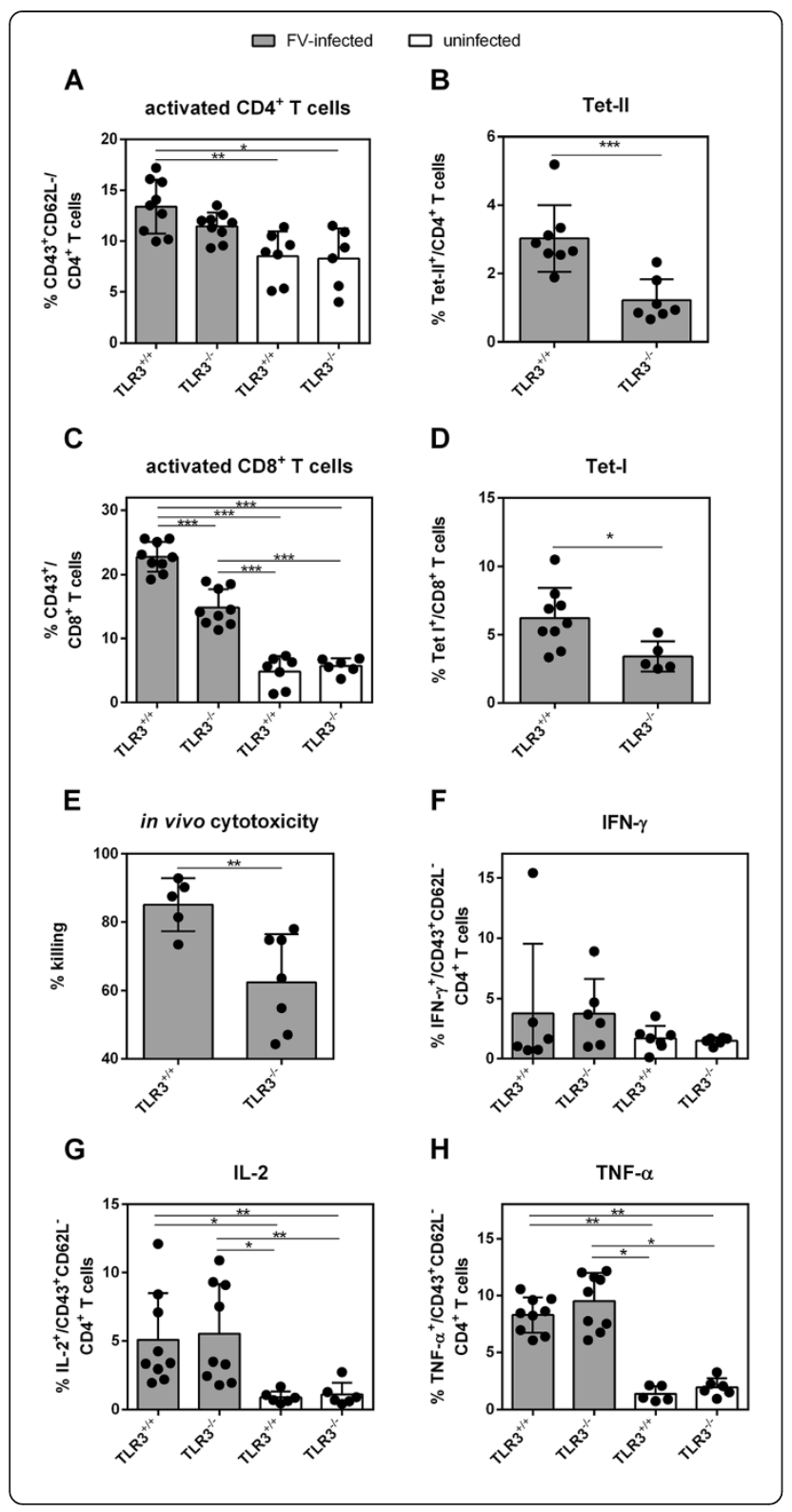

Figure $5 \mathrm{FV}$-specific $\mathrm{CD} 4^{+}$and $\mathrm{CD} 8^{+} \mathrm{T}$ cell responses in FV-infected $\mathrm{TLR}^{+/+}$and $\mathrm{TLR}^{-/-}$mice. $\mathrm{TLR3}^{+/+}$and $\mathrm{TLR}^{-/-}$ mice were infected with 20,000 SFFU of FV. $\mathrm{CD}^{+}$and $\mathrm{CD} 8^{+} \mathrm{T}$ cells were analyzed at $10 \mathrm{dpi}$ by flow cytometry. Percentages of activated $\left(\mathrm{CD}_{3}{ }^{+} \mathrm{CD}_{2} \mathrm{~L}^{-}, \mathbf{A}\right) \mathrm{CD}^{+} \mathrm{T}$ cells were determined. For the analysis of virus-specific $\mathrm{CD}^{+}{ }^{+} \mathrm{T}$ cells (B) splenocytes were stained with $\mathrm{MHC}$ class II-antibody tetramers specific for F-MuLV env fn20. To analyze the function of $\mathrm{CD}^{+} \mathrm{T}$ cells, the intracellular expression of IFN- $\gamma$ (C), IL-2 (D) and TNF-a (E) was measured in activated effector CD4 ${ }^{+}$ $\mathrm{T}$ cells. Percentages of activated $\left(\mathrm{CD} 43^{+}, \mathbf{F}\right) \mathrm{CD}^{+} \mathrm{T}$ cells and virus-specific effector $C D 8^{+} T$ cells $(G)$, which are specific for the FV GagL epitope stained for GagL class I tetramers, were analyzed by flow cytometry. Uninfected $\mathrm{TLR}^{+/+}$and $\mathrm{TLR}^{-/-}$mice were used as controls (white bars). At least five mice per group were analyzed and the mean value for each group is indicated by bars and dots.

At least 2 independent experiments were performed. Statistical differences between the groups are indicated by ${ }^{*}$ for $p<0.05$, ${ }^{* *}$ for $p<0.01$ and ${ }^{* *}$ for $p<0.001$. (H) Splenocytes from naive mice were loaded with the FV-specific DbGagL peptide and labeled with CFSE. Target cells were injected intravenously into naive or FV-infected TLR3 ${ }^{+/+}$and TLR3 ${ }^{-/-}$mice. Two hours after transfer, donor cells from spleen were analyzed. The figure shows the percentage of target cell killing in the spleen. Two independent experiments with three mice per group were performed and mean values are shown by bars. Differences between both groups are indicated by ${ }^{* *}$ for $p<0.01$.

high order secondary structures like stem loops which might be targeted by TLR3 $[17,18,51-53]$. A recent study could show that TLR3 recognizes stem structures in single-stranded viral RNA [54] which indicates that TLR3 is a potential immune sensor of retroviruses.

In an earlier study we have used a synthetic ligand for TLR3 (polyinosinic:polycytidylic acid, poly I:C) to treat mice during acute FV infection [55]. Stimulation of TLR3 resulted in a significant reduction in viral loads and prevented virus-induced splenomegaly as well as the onset of lethal erythroleukemia. We showed that $\mathrm{CD}^{+} \mathrm{T}$ cell responses and especially their cytotoxicity (CD107a, GzmB expression) were improved by triggering TLR3 [55]. However, TLR3 stimulation alone can still not mediate complete viral clearance in retroviral infections leading to the development of chronic infections.

Others demonstrated that stimulation of macrophages with poly I:C reduces HIV-1 infection in vitro [56-59] which depends on the expression of microRNA-155 [60]. Lentiviral vectors [61] as well as in vitro transcribed HIV-1 gag mRNA [62] were shown to be sensed by TLR3. Another interesting observation reported that a common polymorphism in the human TLR3 mediates protection from HIV-1 by increased activation PBMCs and the production of the proinflammatory cytokines IL-6 and CCL-3 [63]. This indicates that targeting TLR3 during retroviral infections might improve host immune response and thus reduce viral loads which makes TLR3 as a potential target for antiretroviral immunotherapies. 


\section{Conclusion}

In summary, we used $\mathrm{TLR}^{-1-}$ mice to investigate the role of TLR3 in antiretroviral immunity utilizing the Friend retrovirus mouse model. Viral loads were significantly increased in these mice revealing that TLR3 participates in anti-FV immunity during acute infection. Specifically the cytotoxicity of NK cells and $\mathrm{CD} 8^{+} \mathrm{T}$ cells was significantly impaired in TLR3 ${ }^{-1-}$ mice as compared to those of wild type controls. Triggering TLR3 activation might stimulate cytotoxic effector cells to eliminate virus-infected cells and thus be of interest to treat retroviral infections.

\section{Methods}

Mice

Seven to nine weeks old female C57BL/6 mice $\left(\mathrm{TLR}^{+/+}{ }^{\text {, }}\right.$ $\mathrm{TLR7}^{+/+}$, Charles River Laboratories, Germany) were used for the experiments. Experiments were also done with TLR3 $^{-/-}$mice [15] and TLR7 ${ }^{-1-}$ [64] (Jackson Laboratories, USA) backcrossed more than 10 times on C57BL/6 background. All mice were treated in accordance with the regulations and guidelines of the institutional animal care and use committee of the University of Duisburg-Essen.

\section{Virus and viral infection}

The FV stock used in these experiments was FV complex containing B-tropic Friend murine leukemia helper virus and polycythemia-inducing spleen focus-forming virus. The stock was prepared as a $15 \%$ spleen cell homogenate from $\mathrm{BALB} / \mathrm{c}$ mice infected 14 days previously with 3000 spleen focus-forming units (SFFU). Mice were injected intravenously with $0.1 \mathrm{ml}$ phosphate-buffered saline containing 20,000 SFFU of FV. The virus stock did not contain lactate dehydrogenase-elevating virus.

\section{Detection of FV-infected cells}

Infectious centers (IC) were detected by 10 -fold dilutions of single-cell suspensions onto Mus dunnis cells. Cultures were incubated for 3 days, fixed with ethanol, stained with F-MuLV envelope-specific monoclonal antibody 720 and developed with peroxidase-conjugated goat anti-mouse antibody and aminoethylcarbazol to detect foci [65].

\section{Plasma viral load quantification}

FV plasma viral RNA loads were measured by real-time PCR as previously described [66].

\section{RNA isolation}

Splenic DCs were separated by MACS technology (Miltenyi Biotec) and their total RNA was isolated using TRIzol reagent (Life Technologies) and Pure Link RNA Micro Kit (Life Technologies). Isolated RNA was dissolved in RNasefree water and stored at $-80^{\circ} \mathrm{C}$.

\section{Real time-PCR}

Real time-PCR analysis for the quantification of $P k r$, Ifn$a 4$, Ifn-b, Ifi44 and Tlr3 mRNA was performed using Power SYBR Green RT-PCR kit (Life Technologies) and Quanti Tect Primer assays (Qiagen). Primer sequences (Biomers) for $\beta$-actin were as follows: 5 -aaatcgtgcgtgacatcaaa-3', 5'-caagaaggaaggctggaaaa-3'. The quantitative mRNA levels were performed by using StepOne Software v2.3 (Life Technologies) and were normalized to $\beta$-actin mRNA expression levels.

\section{Generation and culture of myeloid DCs from bone} marrow cells and antigen-specific $\mathrm{T}$ cell proliferation

Bone marrow-derived DCs were generated as described before [67]. BM-DCs from 4 dpi infected $\mathrm{TLR}^{+/+}$and $\mathrm{TLR}^{-/-}$mice were left untreated or loaded with $0.1 \mu \mathrm{g} / \mathrm{mL}$ FV antigen (FV GagL peptide (85-93)). Antigen-specific $\mathrm{CD}^{+} \mathrm{T}$ cells were isolated from TCRtg mice by MACS technology (Miltenyi Biotec) and stained with CellTrace ${ }^{\mathrm{ms}}$ CFSE (Life Technologies). Afterwards, $2.5 \times 10^{5} \mathrm{FV}$-specific $\mathrm{CD}^{+} \mathrm{T}$ cells were co-cultured with $0.5 \times 10^{5}$ BM-DCs. After 3 days, proliferation of $\mathrm{CD}^{+} \mathrm{T}$ cells was assessed by flow cytometry as loss of CellTrace ${ }^{\mathrm{rw}}$ CFSE dye. Numbers of proliferating $\mathrm{CD}^{+} \mathrm{T}$ cells were calculated by the following formula:

$$
\begin{aligned}
\mathbf{n}(\text { proliferating cells })= & \frac{\mathbf{n}(\mathbf{G} 1)}{2}+\frac{\mathbf{n}(\mathbf{G} 2)}{4}+\frac{\mathbf{n}(\mathbf{G} 3)}{8} \\
& +\frac{\mathbf{n}(\mathbf{G} 4)}{16}
\end{aligned}
$$

\section{Cell surface and intracellular staining by flow cytometry}

Cell surface staining was performed using the following antibodies: anti-CD11b (M1/70, Miltenyi Biotec), antiCD11c (N418, BioLegend) anti-CD3 (17A2, eBioscience), anti-CD49b (DX5, eBioscience), anti-CD69 (H1.2 F3, eBioscience), anti-CD86 (GL-1, BioLegend), anti-MHC-II (M5/114.15.2, Miltenyi Biotec), anti-NK1.1 (PK136, BD Bioscience). Dead cells were excluded from analysis (positive for fixable viability dye, eBioscience). For detection of activated $\mathrm{T}$ cells splenocytes were stained with anti-CD4 (GK1.5, eBioscience), anti-CD8 (53-6.7, eBioscience), anti-CD43 (1B11, BioLegend) and anti-CD62L (MEL-14, eBioscience). Intracellular IFN- $\gamma$ (XMG1.2, Miltenyi Biotec), IL-2 (JES6-5H4, Miltenyi Biotec) and TNF- $\alpha$ (MP6XT22, BioLegend) staining was performed as described $[28,29]$. Data were acquired on LSR II flow cytometer (BD Bioscience) and analyses were performed using FACSDiva (BD Bioscience) and Flow Jo (Tree Star, USA) software.

\section{Tetramers and tetramer staining}

Tetramer stainings were performed as described previously [13]. 


\section{In vitro NK cell cytotoxicity assay}

In vitro NK cell cytotoxicity assay was performed using $1 \times 10^{4}$ CFSE stained FBL-3 tumor cells and varying numbers of isolated NK cells from spleen of naive or FVinfected mice by MACS technology (Miltenyi Biotec). The cytotoxic assay was performed in 96-well U-bottom plates. The cells were co-incubated for 24 hours in a humidified $5 \% \mathrm{CO}_{2}$ atmosphere at $37^{\circ} \mathrm{C}$. Cells were washed once, resuspended in buffer containing 7-aminoactinomycin D to exclude dead cells and analyzed by flow cytometry.

\section{In vivo cytotoxicity assay}

The in vivo cytotoxicity assay was performed as previously described [28]. Labeled target cells were transferred into naive or FV-infected TLR3 ${ }^{+/+}$or $\mathrm{TLR}^{-/-}$mice at day 10 post infection.

\section{Statistical analyses}

Statistical analyses and graphical presentations were computed with Graph Pad Prism version 6. Two-group comparisons were done using 2-tailed unpaired Student's $\mathrm{t}$ test. Analyses including several groups were tested using Kruskal-Wallis one-way analysis of variance on ranks and Dunn's multiple comparison test (non-parametric distribution) or the ordinary one-way ANOVA and Bonferroni's multiple comparisons test (parametric distribution). P values less than 0.05 were considered statistically significant.

\section{Abbreviations}

cGAS: Cyclic GMP-AMP synthase; FV: Friend Retrovirus; MDA5: Melanoma Differentiation-Associated protein 5; mDC: Myeloid dendritic cell; MyD88: Myeloid differentiation primary response 88; NK cell: Natural killer cell; PRR: Pattern recognition receptor; RIG-I: Retinoic acid inducible gene I; TLR: Toll-like receptor.

\section{Competing interests}

The authors declare that they have no competing interests.

\section{Authors' contributions}

KG designed the experiments, performed the experiments, analyzed the data, did the statistical analysis and wrote the paper. SF, MSH, BSB and AMS carried out experiments. CJK and ML designed the experiments. MLS and UD conceived the experiments and wrote the paper. All authors read and approved the final manuscript.

\section{Acknowledgements}

This work was supported by a grant from the University Hospital Essen (IFORES) and by the Deutsche Forschungsgemeinschaft (TRR60).

\section{Author details}

IInstitute for Virology of the University Hospital in Essen, University of Duisburg-Essen, Essen, Germany. ${ }^{2}$ Institute for Medical Microbiology of the University Hospital in Essen, University of Duisburg-Essen, Essen, Germany. ${ }^{3}$ Department of Medicine, University of Colorado Denver, Aurora, CO 80045, USA.

Received: 24 October 2014 Accepted: 5 December 2014

Published online: 24 December 2014

\section{References}

1. Akira S, Takeda K: Toll-like receptor signalling. Nat Rev Immunol 2004, 4:499-511.
2. Gao D, Wu J, Wu YT, Du F, Aroh C, Yan N, Sun L, Chen ZJ: Cyclic GMP-AMP synthase is an innate immune sensor of HIV and other retroviruses. Science 2013, 341:903-906.

3. Sun L, Wu J, Du F, Chen X, Chen ZJ: Cyclic GMP-AMP synthase is a cytosolic DNA sensor that activates the type I interferon pathway. Science 2013, 339:786-791.

4. Cai X, Chiu YH, Chen ZJ: The cGAS-cGAMP-STING pathway of cytosolic DNA sensing and signaling. Molecular cell 2014, 54:289-296.

5. Randall RE, Goodbourn S: Interferons and viruses: an interplay between induction, signalling, antiviral responses and virus countermeasures. J Gen Virol 2008, 89:1-47.

6. Gringhuis $\mathrm{Sl}$, van der Vlist M, van den Berg LM, den Dunnen J, Litjens M, Geijtenbeek TB: HIV-1 exploits innate signaling by TLR8 and DC-SIGN for productive infection of dendritic cells. Nat Immunol 2010, 11:419-426.

7. Mogensen TH, Melchjorsen J, Larsen CS, Paludan SR: Innate immune recognition and activation during HIV infection. Retrovirology 2010, 7:54.

8. Beignon AS, McKenna K, Skoberne M, Manches O, DaSilva I, Kavanagh DG, Larsson M, Gorelick RJ, Lifson JD, Bhardwaj N: Endocytosis of HIV-1 activates plasmacytoid dendritic cells via Toll-like receptor-viral RNA interactions. J Clin Invest 2005, 115:3265-3275.

9. Lepelley A, Louis S, Sourisseau M, Law HK, Pothlichet J, Schilte C, Chaperot L, Plumas J, Randall RE, Si-Tahar M, Mammano F, Albert ML, Schwartz O: Innate sensing of HIV-infected cells. PLOS Pathog 2011, 7:e1001284.

10. Pertel T, Hausmann S, Morger D, Zuger S, Guerra J, Lascano J, Reinhard C, Santoni FA, Uchil PD, Chatel L, Bisiaux A, Albert ML, Strambio-De-Castillia C, Mothes W, Pizzato M, Grutter MG, Luban J: TRIM5 is an innate immune sensor for the retrovirus capsid lattice. Nature 2011, 472:361-365.

11. Browne EP, Littman DR: Myd88 is required for an antibody response to retroviral infection. PLoS pathogens 2009, 5:e1000298.

12. Kane M, Case LK, Wang C, Yurkovetskiy L, Dikiy S, Golovkina TV: Innate immune sensing of retroviral infection via Toll-like receptor 7 occurs upon viral entry. Immunity 2011, 35:135-145.

13. Gibbert K, Joedicke JJ, Meryk A, Trilling M, Francois S, Duppach J, Kraft A, Lang KS, Dittmer U: Interferon-alpha Subtype 11 Activates NK Cells and Enables Control of Retroviral Infection. PLoS pathogens 2012, 8:e1002868.

14. Littwitz E, Francois S, Dittmer U, Gibbert K: Distinct roles of NK cells in viral immunity during different phases of acute Friend retrovirus infection. Retrovirology 2013, 10:127.

15. Alexopoulou L, Holt AC, Medzhitov R, Flavell RA: Recognition of doublestranded RNA and activation of NF-kappaB by Toll-like receptor 3. Nature 2001, 413:732-738.

16. Hajjar AM, Linial ML: Modification of retroviral RNA by double-stranded RNA adenosine deaminase. J Virol 1995, 69:5878-5882.

17. Tounekti N, Mougel M, Roy C, Marquet R, Darlix JL, Paoletti J, Ehresmann B, Ehresmann C: Effect of dimerization on the conformation of the encapsidation Psi domain of Moloney murine leukemia virus RNA. J Mol Biol 1992, 223:205-220.

18. Alford RL, Honda S, Lawrence CB, Belmont JW: RNA secondary structure analysis of the packaging signal for Moloney murine leukemia virus. Virology 1991, 183:611-619.

19. Kabat D: Molecular biology of Friend viral erythroleukemia. Curr Top Microbiol Immunol 1989, 148:1-42.

20. Hasenkrug KJ, Dittmer U: The role of CD4 and CD8 T cells in recovery and protection from retroviral infection: lessons from the Friend virus model. Virology 2000, 272:244-249.

21. Yamamoto M, Sato S, Hemmi H, Hoshino K, Kaisho T, Sanjo H, Takeuchi O, Sugiyama M, Okabe M, Takeda K, Akira S: Role of adaptor TRIF in the MyD88-independent toll-like receptor signaling pathway. Science 2003, 301:640-643.

22. Yoneyama M, Suhara W, Fukuhara Y, Fukuda M, Nishida E, Fujita T: Direct triggering of the type I interferon system by virus infection: activation of a transcription factor complex containing IRF-3 and CBP/p300. EMBO J 1998, 17:1087-1095.

23. Doyle S, Vaidya S, O'Connell R, Dadgostar H, Dempsey P, Wu T, Rao G, Sun R, Haberland M, Modlin R, Cheng G: IRF3 mediates a TLR3/TLR4-specific antiviral gene program. Immunity 2002, 17:251-263.

24. Barchet W, Wimmenauer V, Schlee M, Hartmann G: Accessing the therapeutic potential of immunostimulatory nucleic acids. Curr Opin Immunol 2008, 20:389-395.

25. Barbalat R, Ewald SE, Mouchess ML, Barton GM: Nucleic acid recognition by the innate immune system. Annu Rev Immunol 2011, 29:185-214. 
26. Gerlach N, Schimmer S, Weiss S, Kalinke U, Dittmer U: Effects of Type I Interferons on Friend Retrovirus Infection (Erratum). J Virol 2007, 81:6160

27. Gerlach N, Schimmer S, Weiss S, Kalinke U, Dittmer U: Effects of type I interferons on Friend retrovirus infection. J Virol 2006, 80:3438-3444.

28. Zelinskyy G, Dietze KK, Husecken YP, Schimmer S, Nair S, Werner T, Gibbert K, Kershaw O, Gruber AD, Sparwasser T, Dittmer U: The regulatory T-cell response during acute retroviral infection is locally defined and controls the magnitude and duration of the virus-specific cytotoxic T-cell response. Blood 2009, 114:3199-3207.

29. Zelinskyy G, Kraft AR, Schimmer S, Arndt T, Dittmer U: Kinetics of CD8+ effector $\mathrm{T}$ cell responses and induced CD4+ regulatory $\mathrm{T}$ cell responses during Friend retrovirus infection. Eur J Immunol 2006, 36:2658-2670.

30. Browne EP: Toll-like receptor 7 inhibits early acute retroviral infection through rapid lymphocyte responses. J Virol 2013, 87:7357-7366.

31. Marques R, Antunes I, Eksmond U, Stoye J, Hasenkrug K, Kassiotis G: B lymphocyte activation by coinfection prevents immune control of friend virus infection. J Immunol 2008, 181:3432-3440.

32. Gururajan M, Jacob J, Pulendran B: Toll-like receptor expression and responsiveness of distinct murine splenic and mucosal B-cell subsets. PloS one 2007, 2:e863.

33. Mandl JN, Barry AP, Vanderford TH, Kozyr N, Chavan R, Klucking S, Barrat FJ, Coffman RL, Staprans SI, Feinberg MB: Divergent TLR7 and TLR9 signaling and type I interferon production distinguish pathogenic and nonpathogenic AIDS virus infections. Nat Med 2008, 14:1077-1087.

34. Lee H, Komano J, Saitoh Y, Yamaoka S, Kozaki T, Misawa T, Takahama M, Satoh T, Takeuchi O, Yamamoto N, Matsuura Y, Saitoh T, Akira S: Zinc-finger antiviral protein mediates retinoic acid inducible gene l-like receptorindependent antiviral response to murine leukemia virus. Proc Natl Acad Sci U S A 2013, 110:12379-12384.

35. Iwasaki A, Medzhitov R: Toll-like receptor control of the adaptive immune responses. Nat Immunol 2004, 5:987-995.

36. Kawai T, Akira S: Antiviral signaling through pattern recognition receptors. J Biochem 2007, 141:137-145.

37. Akira S, Takeda K, Kaisho T: Toll-like receptors: critical proteins linking innate and acquired immunity. Nat Immunol 2001, 2:675-680.

38. Iwasaki A, Pillai PS: Innate immunity to influenza virus infection. Nat Rev Immunol 2014, 14:315-328

39. Koyama S, Ishii KJ, Kumar H, Tanimoto T, Coban C, Uematsu S, Kawai T, Akira S: Differential role of TLR- and RLR-signaling in the immune responses to influenza A virus infection and vaccination. J Immunol 2007, 179:4711-4720.

40. Heer AK, Shamshiev A, Donda A, Uematsu S, Akira S, Kopf M, Marsland BJ: TLR signaling fine-tunes anti-influenza $B$ cell responses without regulating effector T cell responses. J Immunol 2007, 178:2182-2191.

41. Xia J, Winkelmann ER, Gorder SR, Mason PW, Milligan GN: TLR3- and MyD88-dependent signaling differentially influences the development of West Nile virus-specific B cell responses in mice following immunization with RepliVAX WN, a single-cycle flavivirus vaccine candidate. J Virol 2013, 87:12090-12101

42. Lazear HM, Pinto AK, Ramos HJ, Vick SC, Shrestha B, Suthar MS, Gale M Jr, Diamond MS: Pattern recognition receptor MDA5 modulates CD8+ T cell-dependent clearance of West Nile virus from the central nervous system. J Virol 2013, 87:11401-11415.

43. Errett JS, Suthar MS, McMillan A, Diamond MS, Gale M Jr: The essential, nonredundant roles of RIG-I and MDA5 in detecting and controlling West Nile virus infection. J Virol 2013, 87:11416-11425.

44. Suthar MS, Ma DY, Thomas S, Lund JM, Zhang N, Daffis S, Rudensky AY, Bevan MJ, Clark EA, Kaja MK, Diamond MS, Gale M Jr: IPS-1 is essential for the control of West Nile virus infection and immunity. PLoS Pathog 2010, 6:e1000757.

45. Szretter KJ, Daffis S, Patel J, Suthar MS, Klein RS, Gale M Jr, Diamond MS The innate immune adaptor molecule MyD88 restricts West Nile virus replication and spread in neurons of the central nervous system. $J$ Virol 2010, 84:12125-12138.

46. Daffis S, Samuel MA, Suthar MS, Gale M Jr, Diamond MS: Toll-like receptor 3 has a protective role against West Nile virus infection. J Virol 2008, 82:10349-10358

47. Jin YH, Kim SJ, So EY, Meng L, Colonna M, Kim BS: Melanoma differentiationassociated gene 5 is critical for protection against Theiler's virus-induced demyelinating disease. J Virol 2012, 86:1531-1543.

48. Jin YH, Kaneyama T, Kang MH, Kang HS, Koh CS, Kim BS: TLR3 signaling is either protective or pathogenic for the development of Theiler's virus-induced demyelinating disease depending on the time of viral infection. J Neuroinflammation 2011, 8:178.

49. Tabeta K, Georgel P, Janssen E, Du X, Hoebe K, Crozat K, Mudd S, Shamel L, Sovath S, Goode J, Alexopoulou L, Flavell RA, Beutler B: Toll-like receptors 9 and 3 as essential components of innate immune defense against mouse cytomegalovirus infection. Proc Natl Acad Sci U S A 2004, 101:3516-3521.

50. Moore MD, Hu WS: HIV-1 RNA dimerization: It takes two to tango. AIDS Rev 2009, 11:91-102.

51. Russell RS, Liang C, Wainberg MA: Is HIV-1 RNA dimerization a prerequisite for packaging? Yes, no, probably? Retrovirology 2004, 1:23

52. Greatorex J: The retroviral RNA dimer linkage: different structures may reflect different roles. Retrovirology 2004, 1:22

53. Watts JM, Dang KK, Gorelick RJ, Leonard CW, Bess JW Jr, Swanstrom R, Burch $\mathrm{CL}$, Weeks KM: Architecture and secondary structure of an entire HIV-1 RNA genome. Nature 2009, 460:711-716.

54. Tatematsu M, Nishikawa F, Seya T, Matsumoto M: Toll-like receptor 3 recognizes incomplete stem structures in single-stranded viral RNA. Nat Commun 2013, 4:1833.

55. Gibbert K, Dietze KK, Zelinskyy G, Lang KS, Barchet W, Kirschning CJ, Dittmer $\mathrm{U}$ : Polyinosinic-polycytidylic acid treatment of Friend retrovirus-infected mice improves functional properties of virus-specific T cells and prevents virus-induced disease. J Immunol 2010, 185:6179-6189.

56. Wang $X$, Chao W, Saini M, Potash MJ: A common path to innate immunity to HIV-1 induced by Toll-like receptor ligands in primary human macrophages. PLoS One 2011, 6:e24193.

57. Zhou Y, Wang X, Liu M, Hu Q, Song L, Ye L, Zhou D, Ho W: A critical function of toll-like receptor- 3 in the induction of anti-human immunodeficiency virus activities in macrophages. Immunology 2010, 131:40-49.

58. Tsang J, Chain BM, Miller RF, Webb BL, Barclay W, Towers GJ, Katz DR, Noursadeghi M: HIV-1 infection of macrophages is dependent on evasion of innate immune cellular activation. AIDS 2009, 23:2255-2263.

59. Suh HS, Zhao ML, Choi N, Belbin TJ, Brosnan CF, Lee SC: TLR3 and TLR4 are innate antiviral immune receptors in human microglia: role of IRF3 in modulating antiviral and inflammatory response in the CNS. Virology 2009, 392:246-259

60. Swaminathan G, Rossi F, Sierra LU, Gupta A, Navas-Martin S, Martin-Garcia J: A role for microRNA-155 modulation in the anti-HIV-1 effects of Toll-like receptor 3 stimulation in macrophages. PLoS Pathog 2012, 8:e1002937.

61. Breckpot K, Escors D, Arce F, Lopes L, Karwacz K, Van Lint S, Keyaerts M, Collins M: HIV-1 lentiviral vector immunogenicity is mediated by Toll-like receptor 3 (TLR3) and TLR7. J Virol 2010, 84:5627-5636.

62. Kariko $\mathrm{K}, \mathrm{Ni} \mathrm{H}$, Capodici J, Lamphier M, Weissman D: mRNA is an endogenous ligand for Toll-like receptor 3. J Bio/ Chem 2004, 279:12542-12550.

63. Sironi M, Biasin M, Cagliani R, Forni D, De Luca M, Saulle I, Lo Caputo S, Mazzotta F, Macias J, Pineda JA, Caruz A, Clerici M: A common polymorphism in TLR3 confers natural resistance to HIV-1 infection. J Immuno/ 2012, 188:818-823.

64. Hemmi H, Kaisho T, Takeuchi O, Sato S, Sanjo H, Hoshino K, Horiuchi T, Tomizawa H, Takeda K, Akira S: Small anti-viral compounds activate immune cells via the TLR7 MyD88-dependent signaling pathway. Nat Immunol 2002, 3:196-200.

65. Dittmer U, Brooks DM, Hasenkrug KJ: Characterization of a live-attenuated retroviral vaccine demonstrates protection via immune mechanisms. J Virol 1998, 72:6554-6558.

66. Smith DS, Guo K, Barrett BS, Heilman KJ, Evans LH, Hasenkrug KJ, Greene WC, Santiago ML: Noninfectious retrovirus particles drive the APOBEC3/Rfv3 dependent neutralizing antibody response. PLoS Pathog 2011, 7:e1002284.

67. Balkow S, Krux F, Loser K, Becker JU, Grabbe S, Dittmer U: Friend retrovirus infection of myeloid dendritic cells impairs maturation, prolongs contact to naive T cells, and favors expansion of regulatory T cells. Blood 2007, 110:3949-3958. 